\title{
The Devil's Long Tail: Religious Moderation and Extremism on the Web
}

Kieron O'Hara, University of Southampton

David Stevens, University of Nottingham

The Web caters to

niche markets as

easily as it does

to mainstream

tastes. Will it help

extreme religious

groups achieve

unprecedented

prominence?

$\mathrm{n}$ important thesis for the future of the Web, particularly for
$\mathrm{e}$-commerce, is Chris Anderson's long-tail theory. ${ }^{1}$ In the language of economics, the traditional marketplace best satisfies the bulge of the normal demand curve, where most consumers congregate, thanks to economies of scale.

The traditional market badly serves the tail of the curve (that is, the demand for less popular items), because those economies don't exist on such a small scale. The Web removes many costs traditionally associated with market operations, thus fattening the tail-that is, allowing businesses to cater to a longer tail.

In this article, we examine this theory with regard not to an economic market, but rather to the competitive marketplace of ideas. In a religious context, we interpret the long-tail theory as predicting that the Web will allow extreme or strict sects to flourish in an unprecedented way by helping proponents cater to the long tail online. If this is true, it threatens the orthodox understanding of the dynamics of religious extremism. It would also undermine the associated idea that groups' convergence on the middle ground of religious beliefs cultivates and is cultivated by liberal civic virtues. If radical groups can flourish while preaching virtues diametrically opposed to liberalism, freedom of religion might not be so good for liberalism after all.

\section{Religious Freedom and Religious Markets}

The 18th-century Enlightenment thinkers promoted rationality and strongly opposed religious irrationalism, or what was called enthusiasm. Many, including David Hume, held the intuitive position that government sponsorship of moderate religion would help damp down extremism. A "ghostly practitioner" (Hume's phrase) who relied on adherents for financial support would move to extreme positions "to excite the languid devotion of his audience," but if the government paid salaries to the clergy of established churches, it would be "superfluous for them to be farther active than merely to prevent their flock from straying in quest of new pastures."2 
However, in his theory of market societies, The Wealth of Nations, the economist and philosopher Adam Smith denied this intuitive doctrine, arguing instead that state sponsorship would merely aid extremism by deincentivizing moderates and increasing the vigor of religious enthusiasts. "It is with them as with the hussars and light infantry of some armies; no plunder, no pay." 3 A free religious marketplace was the way, paradoxically, to promote moderation. With total freedom of conscience, one would expect this to create "a great multitude of religious sects" that would be forced to compete for the center ground.

The teachers of each sect, seeing themselves surrounded on all sides with more adversaries than friends, would be obliged to learn that candour and moderation which is so seldom to be found among the teachers of those great sects whose tenets, being supported by the civil magistrate, are held in veneration by almost all the inhabitants of extensive kingdoms and empires... The teachers of each little sect, finding themselves almost alone, would be obliged to respect those of almost every other sect, and the concessions which they would mutually find it both convenient and agreeable to make to one another, might in time probably reduce the doctrine of the greater part of them to that pure and rational religion, free from every mixture of absurdity, imposture, or fanaticism, such as wise men have in all ages of the world wished to see established. ${ }^{3}$

Smith's view seems to have been vindicated. The more controversial part of his claim was that this multiplicity of disestablished religious groups would converge on the moderate center ground. The reason for this, he conjectured, would be that because the clergy would depend financially on donations from their flock, they would naturally seek to maximize membership. Because most potential adherents exist in the moderate center ground, religious groups would gravitate toward the center. Hence, there is a feedback loopless-rigid doctrine puts off fewer people, while a desire to increase membership will engender compromise and consensus. Churches that do not take practical steps to move toward a more consensual position will fail to exploit economies of scale and tend to wither.

Smith's observations led to the theory of the church-sect cycle. The church-sect cycle explains the persistence of small but "radical" sects and the seemingly eternal recurrence of the splintering of religious groups-the rise, decline, and fragmentation of denominations. ${ }^{4}$

The logic of the church-sect cycle is a continual process of movement from a position in tension with the social environment to one in harmony with it, until a split occurs and a new sect arises that seeks to assert a new hightension position. As a sect grows and begins to attract many members, it inevitably moderates its positions. Popularity and security come at the price of having to accommodate a wider array of members. The largest pool of potential members occupies the moderate center ground-of the social environment-so sects gravitate to this pool of potential adherents. But those who desire a higher-tension version of the faith become increasingly restless and dissatisfied, until a rift occurs and a splinter group moves to reaffirm the old position by splitting with the main group and forming a new sect. ${ }^{4}$

What explains the predominance of moderate adherents is the low cost of participation. If a religious group's beliefs and practices are harmonious with the surrounding social environment, there is little or no cost to participate. The adherent doesn't have to change his or her beliefs, morals, diet, daily rituals, dress, or language. The benefits of religious participationspiritual and physical well-being, social recognition, collaborative goods, and the like-accrue with no outlay from the individual.

Similarly, this also explains the persistence of membership by a smaller set of people in radical sects. Here, the membership costs are higheroften much higher-including differences from the social environment in such things as diet, dress, rituals, and so forth, as well as an enclave mentality and even group persecution. High costs deter free riding; those who remain members are playing their part through costly participation. Yet members perceive the benefits as also being much higher. They see goods such as group solidarity and higher spiritual worth gained through sacrifice as outweighing the costs.

The Mormons (the Church of Jesus Christ of Latter-Day Saints) provide an excellent example of this process. Early in their history, the Mormons were persecuted because of their heterodox views of polygamy and the nature (and purpose) of Jesus and the Trinity, and because of their strange foundational myth of the transfer of the Book of Mormon to Joseph Smith. The persecution culminated in Smith's assassination, and the cult relocated from Missouri (where revelation decreed it should be based) to sparsely populated Utah. As the church grew, it moved toward the center, with economic and theological factors playing a part. Weeks after the US Supreme Court upheld Congress' decision to enforce the forfeiture of the Mormon Church's property because of its support for polygamy, the church published its 1890 Manifesto, renouncing 
the practice. In the face of civil rights protests in 1978, the Mormon Church revoked its ban against black priests. Now, the Church is the fourthlargest in the United States and one of the fastest growing worldwide. Mormons such as the Osmonds and, more recently, Mitt Romney have become mainstream figures.

However, the 1890 Manifesto also sparked a series of splits, as various fundamentalist cults moved away from the consensual position. The Apostolic United Brethren is one of the most moderate, and probably the largest, with just under 10,000 adherents. The more extreme Fundamentalist Church of Jesus Christ of Latter Day Saints, on the other hand, has suffered since its president, Warren Jeffs, was convicted of accessory to rape for arranging illegal marriages between men and underage girls. Although it remains comparable in size to the Apostolic United Brethren, the identity of its current leader is unknown.

A corollary of the church-sect cycle is what Nancy Rosenblum has termed the logic of congruence. ${ }^{5}$ Participation in groups helps cultivate certain values and virtues in the members, the nature of which depends on the nature of the group in question. Membership of moderate groups that exist in little tension with the surrounding social environment tends to produce individuals predisposed to uphold and perpetuate the values and virtues of that environment. For Adam Smith, the logic of congruence was an extremely useful social benefit. The free market in religion would create civically virtuous citizens minded to uphold the basic pillars of liberal society.

\section{Online Religion and Extremism}

The theoretical analysis based on Smith's free-market philosophy has been borne out over the intervening years. However, two new ideas make Smith's analysis worth revisiting. First, the Web has been associated, rightly or wrongly, with an increase in religious extremism. Second, many commentators have asserted that the Web, by removing the friction in information flow, has effected a fundamental change to market structures. Given the juxtaposition of these two developments, it's worth asking whether changes to the free market of religious ideas wrought by the Web have been a cause of extremism. In this section, we'll examine the first idea; in the next, we'll look at the second.

Certainly, extremists are using the Internet. One survey found that the Internet was a powerful tool for hate groups to reach an international audience, recruit members, link diverse groups, and achieve maximum image control. ${ }^{6}$ Terror groups have used the Internet for communication, data mining, networking, recruitment, mobilization, providing instructions and online manuals (for things such as bomb-making), planning and coordination, fundraising, and attacking rival terrorists. ${ }^{7}$

Frictionless information markets facilitate distributed group dynamics as well as reducing costs. In a faceto-face world, where sect members would communicate in each other's physical presence, a small number of people would be a handicap. A sect of 6,000 members randomly distributed across the globe would have minimal group dynamics. But online, they could use Web resources to communicate and to promote solidarity. On Facebook, 6,000 friends would be a large number to have. Even a very small percentage of cyberspace is a lot of people.

Technology is a friend to the spread of religious ideas. In a world of media with high entry barriers (TV, radio, newspapers), ideas markets are driven by scarcity. On the Web, with low barriers to entry, they are characterized by abundance. Religious works are often given away free (see, for example, www.freekoran.com/index.php), and texts are available online. Biblical texts can be sent to your Psalm Pilot and wrestled with on large discussion spaces (such as www.ebible. com). You can download a GodCast (www.godcast.org). You can even be a censor: Yusufali is a Trojan worm that works its way into a remote computer's hard disc, then censors objectionable Web sites by minimizing the browser and substituting appropriately stern verses from the Qur'an.

But the low barriers to entry mean that more texts are being distributed than in the days of scarce ideas. Some changes appear (to an outsider) frivolous-the GodCast website includes a translation of Biblical texts into Klingon. Jediism (www.jedi-church. com) and Matrixism (www.geocities. com/matrixism2069) now claim to be genuine religions. Other changes are more challenging - it has been argued that Qur'anic texts and commentaries distributed most frequently online are those that accentuate the differences between Islam and Christianity and Judaism, rather than those acknowledging their common roots and assumptions. This wider distribution is important at a time when religiosity is growing and yet there is profound ignorance about religions, even in very religious countries. A scarce supply of religious texts corrals popular religious thought into a relatively strict space; abundance means that there are no restrictions of availability to provide a filter.

Individual entrepreneurs can be better at engaging with people than major churches. Their interaction 
models are decentralized, two-way, and networked, rather than centralized, one-way, and hierarchical. The result feels more like a conversation than a lecture. Web technology has clearly changed the nature of the religious interaction. The Web is now being used to create environments for prayer, meditation, and pilgrimages (to cybershrines like www. iol.ie/ readout/mta; or go to www. sainthood.com to create your own). In the course of this it will tend to alter the effects of these kinds of religious experience. The Web, combined with widespread satellite television, has reduced the localism formerly prominent in many religions and created a technologically mediated "global" religiosity.

Use of the Web is skewed toward the young and so helps to change church and sect demographics. In general, older people are more mainstream in their belief, so the online demography again facilitates fragmentation and aggravates the churchsect cycle.

The radical heterogeneity of online behavior means that "normal" behavior is harder to find online. People behave in different ways; furthermore, they understand a given online situation differently. Some users are highly experienced and others inexperienced. For example, analysis of behavioral networks generated by patterns of network traffic shows that Internet users' behavior is so marked by heterogeneity that it's meaningless to develop models for average Internet use. ${ }^{8}$ There is no average Web user, and, a fortiori, that makes it easier (indeed trivial) for a sect member to diverge from the mean.

The question is whether these perceived changes stack up to produce a genuinely qualitative change in the marketplace of religious ideas and the church-sect cycle. Can we say with any confidence that the new technologies have damaged moderation? The arguments we have enumerated in this section are weighty. However, have extreme cults gained prominence as a byproduct of terrorist actions of groups such as al-Qaeda and Aum Shinrikyo, and are changes in communication technology secondary to willingness to abuse weapons of mass destruction in ways that invite media coverage?

\section{The Religious Market in Cyberspace}

If the nature of strict or extreme religious activity does seem to be changing, how has the Web contributed to that? We will try to address this question by looking first at Cass Sunstein's theories about personalization, then exploring Anderson's long-tail theory in this context, and finally assessing the relevance of empirical evidence that seems to undermine the long-tail theory.

\section{The Daily Me}

The logic of congruence that tends to drag extremists to the center can be sidestepped if the adherent personalizes the content he or she receives. As Sunstein has argued, it's easy for a Web user to avoid information that may contradict his deeply held beliefs. ${ }^{9}$ The public space through which we all have to move offline does not exist online. Internet users can avoid general information aggregators, such as the $\mathrm{BBC}$ or large national newspapers' Web sites, in favor of partial sites, such as blogs, that preach to the converted. Indeed, network analysis tends to back up Sunstein's claim, showing that political blogs tend to link to other blogs that support similar rather than opposing views. Arguments that blogs help provide the "wisdom of crowds" are misplaced, because they assume some method of aggregation of views that does not occur in the blogosphere. ${ }^{9}$

The result, argues Sunstein, is that extreme views receive large amounts of positive feedback and become entrenched. If the extremist intends to impose his views through a political process, this is unproblematic: the political process itself (whether democratic or bureaucratic) will involve persuasion and therefore (such are the rules of interlocution) the risk of receiving a convincing opposing argument. But not all extremists interact politically; tight positive-feedback loops for extremist views are dangerous if the extremist-whether religious, such as a suicide bomber, or nonreligious, such as one who undertakes random shootings in school or at work-anticipates acting violently.

\section{The Long Tail}

By lowering the costs of information transfer and reducing the friction of interactions, the Web allows culture to evolve unmediated (or less mediated) by cost considerations. Anderson sets out what he calls "six themes of the Long Tail age," applicable to markets in general, comparing the fortunes of niche products with extremely popular ones. In an offline market, popular goods, which reap economies of scale of production, are often produced at the expense of the niche products, which can't command enough demand to justify the sacrifice of shelf space. ${ }^{1}$ Each of these six themes affects the "theological economy" of the church-sect cycle, if we interpret "popular item" as a mainstream religion, church, theology, or ideology, and "niche product" as a more extreme position or sect.

- In most markets, there are far more niche goods than popular items. In theological terms, we might see this as the existence of a small number 
of large, stable, inertial, institutionalized religions, surrounded by countless theological variants that don't attract many adherents.

- Digital technologies, including online distribution, search, and broadband have lowered the costs of reaching those niches. A religious ideology is largely information and can be discovered and distributed cheaply using search engines, tagging, and so on.

- Filters, including search engines, recommender systems, rankings, and social networks are required to drive demand down a long tail. Such filters are likely to be present as someone curious and dissatisfied about religion engages with online communities such as a group of Facebook friends, a MySpace group, an Internet forum, a bulletin board, or a mailing list. Books purchased on Amazon will include further recommendations. Blogs will link to related blogs.

- Exploitation of the long tail causes demand to flatten. As niches attract more consumers, demand for the bigger hits declines. As people are drawn to strict sects they've learned about, adherence to major churches appears to decline, especially as churches and sects are rivals, in that membership in one religious group is generally incompatible with membership in others. As information has spread about alternatives, adherence to mainstream religions has declined.

- Niches add up. Small sects are individually insignificant, but their total number can be significant. The number of "unaffiliated Christians" (that is, persons professing Christianity in censuses but not claiming affiliation with a particular group) is 119.5 million worldwide, and 48.6 million in the US (up from 18.8 million in the US in 1900).
- A long-tail market reveals the natural shape of demand. The picture of religious belief is presented with fewer distribution bottlenecks, and people can seek out smaller sects closer to their individual beliefs.

Anderson suggests three forces produce the long tail. ${ }^{1}$ First, the tools of production are democratized, which lengthens the tail by providing more niche goods. For our discussion, this links to the technology for religious communication, including Web 2.0 (many sects share videos on YouTube, for instance). Extremist, extralegal groups may also use security systems and privacy-enhancing technologies. The second force is the democratization of the tools of distribution-in other words, the aggregation of demand through search engines, tagging, social networking, and so on. This fattens the tail by providing more access to niche goods. Third, supply and demand must be connected, so filters send people down toward the niches at the tail.

The Web provides a means for people to sidestep the problems and lower the costs of being in an extremist sect. Public hostility and indifference can be ignored. The only cost that the Web leaves untouched is the "pure" cost of ritual, which is the chief mechanism for ensuring loyalty and continuity.

\section{The Empirical Critique of the Long Tail}

The long-tail theory has recently come under some pressure from empirical analyses of actual markets. Anita Elberse has argued that the market for music downloads and DVD rentals hasn't changed as predicted, and that retailers are still rational to focus on the blockbusters. ${ }^{10}$ An analysis of music downloads by Will Page shows that the curve is a log-normal curve with little in the tail- 0.4 percent of tracks accounted for 80 percent of downloads. ${ }^{11}$ R. Alexander Bentley, Paul Ormerod, and Mark Madsen confirm that when consumer preference is very changeable, the inventory size that maximizes profit for a retailer is pretty small. ${ }^{12}$

This doesn't necessarily undermine the long-tail theory in all fields, though. Matthew Salganik, Peter Dodds, and Duncan Watts provided an insight into what is going on by looking at music downloads among a large sample of young people. ${ }^{13}$ The volunteers were divided into groups, some of which received recommendation feedback based on the purchases of other members of the group, while others did not. The market shape of the groups without recommendations had longer tails. The groups with recommendations had more traditionally shaped market curves, but the "hits" in each group were different. That is, the groups all showed a tendency to converge, but around a different set of songs.

This implies that a key factor is intramarket communication. The original short-tail market form happened because of the friction in the market, which was removed by Web technology. Recommender systems seem to substitute for the friction by focusing preferences, especially in volatile markets such as music downloads, on items that have previously sold well. The friction has been, in effect, replaced in the system. Collaborative filtering requires historical sales data, so items that have not sold well are disadvantaged.

How does this play out in the marketplace for religious ideas? On the one hand, there are no recommender systems ("If you are an adherent of this deity, you may also like ..."), and collaborative filtering of religious ideologies would 
be hard. On the other hand, religious sectaries do seek out others-a small hard core of comrades seems important for many types of religious experience. Furthermore, although religions themselves are hard to filter collaboratively, important associated itemsbooks, videos of sermons, and so oncan be subject to recommendations. This will tend to narrow the field.

These factors will probably shorten the tail in the religious market. However, given the lack of a dedicated pattern of recommendations, and given the weight of the considerations we discussed earlier in this article, it seems reasonable at this stage to assume that such markets have a longer tail than they did before the introduction of Web technology. Empirically testing this hypothesis would be an important step for research in this area.

\section{Policy Issues and Applications}

The Web depends for its function on decentralization of control. No central body determines who should link to whom, or what one can put in one's Web page. This is an engineering essential, as any centralization would create bottlenecks that would not allow the Web to scale.

If our arguments are correct, the policy issue for those who wish to reduce extremism online boils down to the question of how to shorten and fatten the tail of the religious market. In many ways, this is what Sunstein's policy proposals attempt to do, by subsidizing and supporting deliberative domains, adopting formal codes of conduct, and linking to sites with opposite points of view. ${ }^{9}$ Our earlier arguments imply that the provision of information about other users' preferences would be a method for doing this, and new technologies such as the Semantic Web could be exploited for these purposes.
However, the difficulty for policymakers is that to expose relatively extreme ideas to arguments from more moderate positions, it is necessary to give them air time. Information filters must be trusted-many consumers trust Amazon's recommendations, but if they always pointed away from some publishers and toward others they would not be trusted, and would therefore not work. To squeeze and shorten the tail of the religious marketplace, information provision must be trusted-and a distrust of authorities, of course, is part of the problem of religious extremism.

Debate must be visible, free, and fair; otherwise there will be little effect. It is in extremists' interests to lengthen the tail, and it seems that their best strategy is to provide information about their ideas in the marketplace without also providing information about others' preferences and behaviors. The ideal extremist will be informed about ideas, but socially isolated. Thus, the personalization systems that worry Sunstein can only be part of the problemcollaborative filtering is a personalization technology that seems to shorten tails. So also, extremists will try to discourage debate and suppress links to opposite points of view, in order to create the type of intellectual ghetto to which Sunstein objects.

\section{$\mathbf{H}$} eterodox sects have always appeared and disappeared. They have often been suppressed with violence. They have often been linked with a growing assertiveness in classes of people hitherto denied a voice. The Web has a number of advantages for such people, including the ability to cater to niche tastes, as Anderson argues.

There are also reasons to think that the Web may have changed the terms of religious trade qualitatively as well as quantitatively. It's impossible to impose a heavy-handed secular content editor, because it would break the Web. Furthermore, the churchsect cycle strongly implies that extremism won't go away; however, fears that it will spread beyond a hard core are likely to be overblown. Like the poor, the strictly religious will always be with us.

An online free market in religion would be a bumpy ride, and with the frictionless communication the Web facilitates, the ride may be bumpier than before. Terrorists and extremists use the Web with great facility, just as they used the printing press and roads. We don't have sufficient evidence that this relatively new form of communication technology has qualitatively changed the nature of religious groupings. But in policy terms, we're beginning to see the limits of Anderson's long-tail thesis, and it is in the interests of the opponents of extremism to ensure that those limits persist in the marketplace for religious ideas.

\section{References}

1. C. Anderson, The Long Tail: How Endless Choice is Creating Unlimited Demand, Random House Business Books, 2006.

2. D. Hume, The History of England, vol. III, Liberty Fund, 1983.

3. A. Smith, The Wealth of Nations, books IV-V, Penguin, 1999.

4. R. Finke and R. Stark, The Churching of America 1776-2005: Winners and Losers in Our Religious Economy, Rutgers Univ. Press, 2005.

5. N.L. Rosenblum, Membership and Morals: The Personal Uses of Pluralism in America, Princeton Univ. Press, 2000.

6. P.B. Gerstenfeld, "Hate Online: A Content Analysis of Extremist Internet Sites," Analyses of Social Issues and 


\section{THE AUTHORS}

Kieron O'Hara is a senior research fellow in the School of Electronics and Computer Science, University of Southampton. His interests include the philosophy, politics, and epistemology of technology, particularly the World Wide Web and the Semantic Web. O'Hara has a DPhil in the philosophy of artificial intelligence from the University of Oxford. $\mathrm{He}$ is a research fellow at the Web Science Research Initiative and the Centre for Policy Studies. Contact him atkmo@ecs.soton.ac.uk.

David Stevens is a lecturer in the School of Politics and International Relations, University of Nottingham. His research interests include political philosophy, particularly multiculturalism and group rights, religious fundamentalism, and the impact of technological advances on distributive justice. He was recently an Economic and Social Science Research Council Fellow based at the Research and Information Communication Unit. Stevens has a $\mathrm{PhD}$ in political philosophy from the University of Nottingham. Contact him at david.stevens@nottingham.ac.uk.

Public Policy, vol. 3, no.1, 2003, pp. 29-44.

7. G. Weimann, Terror on the Internet: The New Arena, the New Challenges, US Inst. of Peace Press, 2006.

8. M.R. Meiss, F. Menczer, and A. Vespignani, "Structural Analysis of Behavioral Networks from the Internet," J. Physics
A: Mathematical and Theoretical, vol. 41, no. 22, 2008, www.iop.org/ EJ/article/1751-8121/41/22/224022/ a8_22_224022.pdf.

9. C.R. Sunstein, Republic.com 2.0, Princeton Univ. Press, 2007.

10. A. Elberse, "Should You Invest in the Long Tail?" Harvard Business
Rev., vol. 86, no. 7/8, 2008, pp. 88-96.

11. "Telco 2.0 Exclusive Interview: The 'Long Tail' Interrogated (Part 2)," blog, 12 Nov. 2008, www.telco2.net/ blog/2008/11/exclusive_interview_will_ page.html.

12. R.A. Bentley, P. Ormerod, and M.E. Madsen, "Shelf-Space Strategy in Long-Tail Markets," Physica A, vol. 388, no. 5, 2009, pp. 691-696.

13. M.J. Salganik, P.S. Dodds, and D.J. Watts, "Experimental Study of Inequality and Unpredictability in an Artificial Cultural Market," Science, vol. 311, 10 Feb. 2006, pp. 854-856.

Selected CS articles and columns $\mathrm{cn}$ are also available for free at http://ComputingNow.computer.org. 